University of Nebraska - Lincoln

DigitalCommons@University of Nebraska - Lincoln

The Nebraska Educator: A Student-Led Journal

Department of Teaching, Learning and Teacher

Education

Winter 10-5-2021

\title{
Confronting the Past, Challenging the Future: Linguistic Hegemony, Capitalism, and Neoliberalism in TESOL
}

Crystal Bock Thiessen

University of Nebraska-Lincoln, cbock3@unl.edu

Follow this and additional works at: https://digitalcommons.unl.edu/nebeducator

Part of the Bilingual, Multilingual, and Multicultural Education Commons, and the Teacher Education and Professional Development Commons

Bock Thiessen, Crystal, "Confronting the Past, Challenging the Future: Linguistic Hegemony, Capitalism, and Neoliberalism in TESOL" (2021). The Nebraska Educator: A Student-Led Journal. 62.

https://digitalcommons.unl.edu/nebeducator/62

This Article is brought to you for free and open access by the Department of Teaching, Learning and Teacher Education at DigitalCommons@University of Nebraska - Lincoln. It has been accepted for inclusion in The Nebraska Educator: A Student-Led Journal by an authorized administrator of DigitalCommons@University of Nebraska - Lincoln. 


\title{
Confronting the Past, Challenging the Future: Linguistic Hegemony, Capitalism, and Neoliberalism in TESOL
}

\author{
Crystal Bock Thiessen \\ Department of Teaching, Learning, and Teacher Education \\ University of Nebraska-Lincoln
}

\begin{abstract}
Western capitalistic values that have given shape to contemporary neoliberal ideologies have, for too long now, greatly influenced the field of teaching English to speakers of other languages (TESOL) as a whole, essentially working to continue cycles of injustice and inequality throughout the field despite well-meaning intentions to the contrary. Dominant language ideologies and linguistic hegemony have greatly shaped both socialized and institutional discourse in English and have worked together to help commodify the idea of upward mobility and success for anyone and everyone who "buys-in" to learning English, reflecting neoliberal selling points that are often taken for granted as natural realities. This has resulted in a pervasive maintenance of global social hierarchies despite the fact that the field regularly promotes and markets egalitarian efforts. This critical essay draws upon contemporary research and realities within the field of TESOL to examine the current gap that exists between where the field says it is versus the neoliberal inequalities it inadvertently promotes and maintains. It argues for more deliberate and critical analysis on how these ideological systems have shaped and continue to inform the field as we know it, and how it will be impossible for TESOL to truly serve in the equitable and just capacities in which it strives to place itself without more critical reflection leading to actual and meaningful change.
\end{abstract}

Keywords: TESOL, English language education, language education, neoliberalism, ESL, EFL 


\section{THE NEBRASKA EDUCATOR, VOLUME 6}

White supremacist and colonized ideologies in the field of teaching English to speakers of other languages (TESOL) have existed and informed the profession long before its formal organization, something with which the international TESOL community is really beginning to grapple. Dominant language ideologies and linguistic hegemony have greatly shaped both socialized and institutional discourse in English and have worked together to help commodify the idea of upward mobility and success for anyone and everyone who "buys-in" to learning English, reflecting neoliberal selling points that are often taken for granted as natural realities. It is primarily those who are within the circle (namely White native speakers of English) and who follow the rules of the standardized version of the dominant discourse, however, that truly ever benefit in the manner marketed and sold world over. English language ideologies, and in turn the social and institutional systems that they inform and replicate, reflect the Western capitalistic values contributing to pervasive neoliberal social injustice that must be critically evaluated and challenged for the field of TESOL to meaningfully move forward.

Institutional settings within the English-dominant and capitalistic discourse system repeatedly expose and maintain social inequalities, particularly affecting those who do not fully participate in them. Global capitalism places value in efficiency, progress, increased wealth and happiness for most, with the individual as the basis of society and equal rights granted to all individual members. This egalitarian aspect, however, at the same time denies that very equality, freedom of expression, and individuality to anyone deemed to be outside of the system, a principle that aids in subjugation, discrimination, and "othering" (Bonvillian, 2020; Scollon, Scollon, and Jones, 2012). A capitalistic system inherently requires inequality-much of which stems from racism--to function and grow and has always been informed by the practice of clearly identifying the circles in which equality applies as well as to whom it is granted. In this regard, 


\section{THE NEBRASKA EDUCATOR, VOLUME 6}

the languages of those on the outside of these circles also become othered while languages of power and prestige, such as English, become the "legitimate" languages for progress. In the field of English language education, a neoliberal market is fueled by rhetoric such as "accent reduction," "business English," and "English for academic purposes" that keeps it in a loop of linguistic imperialism hypostatizing white supremacist systems and ideologies (Gerald, 2020). Like the narratives that surround capitalism and neoliberal ventures, pervasive myths of the global spread of the English language are packaged as natural, neutral, and beneficial when they should instead be viewed as cultural constructs produced, promoted, and maintained by colonialism (Pennycook, 2007). There is nothing natural about a language's power; it must be sold and packaged as such through education.

Institutional systems built on inequity work vociferously to maintain that very inequity. A capitalist-bred dominance and control of knowledge by the Global North over the rest of the world perpetuates the hegemony maintained by colonized languages such as English and ensures that the goal of language education is not to "gain a deeper understanding of and empathy for the worldview of speakers of other languages" (Kramsch, 2019, p. 60) but to capitalize on its neocolonial benefits. These benefits, including greed, inequality, and indifference to local and global environments, are "extraordinarily resistant to change" (Klees, 2020, p. 17) and now make up global discourses that "have become the new common sense" (12) and have dominated worldwide agendas for so long. Commodification of the English language as a tangible and individualized asset and the perceived success that comes with it has resulted in English language programs needing to conform to and run off of a business model prioritizing client satisfaction for profitability and sustainability (Litzenberg, 2020). This has also presented a 


\section{THE NEBRASKA EDUCATOR, VOLUME 6}

neoliberal framing of English global educational models worldwide, packaging itself as a crucial component to anyone wanting upward economic and social mobility.

Although the United States has a history of immigration and multiculturalism itself, the loss of immigrant (and Native) mother tongues stemming from linguistic hegemony that recognized "standard American" English as being the authoritative and only path to the innerAmerican circle and ensuring, through its institutions, that it was and still is the dominant discourse (Bonvillian, 2020). Those who "choose" not to partake in this ideology essentially face discrimination that could lead to social and economic disadvantages. Even within the Englishspeaking circle, certain varieties and speakers, namely those that are regarded as "standard" and "White," are given the most authority and stand to receive the most capitalistic gain, namely those who are fluent in the standard variety and look the "part" to use it. This can especially be seen globally in the field of TESOL through concepts such as nativespeakerism, Whiteness (including white supremacy, white normativity, and racism), and native speaker fallacies that inform English language teacher hiring practices and English language educational materials around the world (Gerald, 2020). In this sense, linguistic hegemony is preserved and disseminated through "both the use of the standard [language] and the recognition of its prestige and authority, even by those who don't use it" (Bonvillian, 2020, p. 415). The Colonized systems from which English language education took root has ensured that, despite the best of intentions from many educators, inner and outer circles of English language speakers and learners still exist, despite what is being sold to them.

When it comes to educating ESOL students of color in a neoliberal globalized world, racial biases and inequalities are reproduced in everything from teaching materials and teacher employment to practices and preferences in teaching and learning. The preoccupation with 


\section{THE NEBRASKA EDUCATOR, VOLUME 6}

curriculum in the U.S. promoting "white studies" or rather, "white male studies," is only one part of the civilizational racism that dominates education and that serves to undermine global local knowledges and even replace them altogether, leading to colonial exclusion of knowledge that strives to contain academic knowledge to a Westernized pool (Kubota, 2019). In applied linguistics, this is reproduced through dominant discourse practices and ideas about linguistic legitimacy.

This colonial exclusion of knowledge, however, has dominated the world through systems of slavery, capitalism, and neoliberalism that trickle down into every social, cultural, educational, and economic aspect. A neoliberal approach to child rearing, for example, sees children as investments into which parents need to pour time, money, and resources in order to maximize the greatest return (Gee, 2002). Those who hold the dominant narrative or powerful discourse have the say on what those investments actually look like and whose investments actually benefit from the system once those children become adults, again perpetuating the social inequalities that a truly egalitarian system should supposedly work to dismantle. Learning English then has become the ultimate investment in which those with the means can invest and through which those without the means face disenfranchisement. Stakeholders in the business of English language education--textbook writers, curriculum developers, and the like--profit from reproducing this ideology and packaging "great Western deeds and thoughts" while abstaining from critically evaluating or addressing its savage past (Pennycook, 2007; Macedo, 2019). As a colonized foreign/second language, English language instruction often overly relies on grammar and superficial communication skills, and educators can easily "fall prey to a paternalistic zeal to save their students from their non-colonial language-speaker's status" (Macedo, 2019, p. 15) 


\section{THE NEBRASKA EDUCATOR, VOLUME 6}

much in the same way that former colonists attempted to inoculate convictions of inferiority into the physical, spiritual, cultural, and linguistic beliefs of the conquered people.

When languages, dialects, and accents are "othered" within a Utilitarian and neoliberal system, injustices against those speakers often become the natural order of things and are replicated and maintained throughout the institutions of the dominant discourse. After neoliberalism gets involved, that "natural order" then gets packaged, marketed, and sold to those willing to pay for it, which, in contemporary times, is done so through required English language courses, expensive English language tutoring, high stakes proficiency exams like the TOEFL or IELTS, and Intensive English Program enrollment. The lifelong process of human socialization takes place through and in relation to institutions, such as education, healthcare, and law, acculturating those who both choose or are denied participation (Scollon, Scollon, and Jones, 2012). Traditionally in a capitalist system, education itself is seen as necessary to the productivity and employability of an individual. The neoliberal "human capital discourse" reflects this as well, almost completely ignoring education's value outside of skills for work (Klees, 2020, p. 11). Under this system, learning English is packaged and sold as the ultimate educational tool one needs for success in life (also known in neoliberal terms as the workforce). While the field of TESOL works to "prepare for success" those who are often systemically oppressed--or at least the full benefits--of being within the dominant circle, the current Black Lives Matter civil rights movement has highlighted just how many are truly left out of it and are actually harmed by it altogether. Bonvillian (2020) has updated her own text on language, culture, and communication to address it directly, stating that institutional portrayals of the dominant society as tolerant and acceptable "provide the context to criticize people who point out racism and other forms of discrimination... [ensuring that] it is the antiracist positions that 


\section{THE NEBRASKA EDUCATOR, VOLUME 6}

can be described as being extreme" (445). This pushback on the dominant discourse, through means such as protesting and trangressive texts (Scollon, Scollon, and Jones, 2012), becomes a major (and for many in power, an uncomfortable) pushback on Utilitarianism/capitalism and the white supremacist and racist ideologies that both created it and are necessary for its survival in the current state.

Although there are many English language professionals who are concerned with addressing these ideologies, "there is significantly less work done unpacking whiteness and how it has always served as the driving force behind ELT" (Gerald, 45), which is actually detrimental to the very population TESOL claims to serve. Privileges of Whiteness and nativerspeaker-like status are the promised prizes of acceptance and success sold in a neoliberal market, but are actually grounded in unattainable realities. The prestige that is often afforded to white native English speakers such as English language teaching positions (with or without teaching experience) ensures that nonnative English-speaking English language teachers, who constitute the majority of the world's English teachers, often find themselves contending both socially and professionally with the perfectly-situated monolingual/monocultural native speaker abstraction (Kramsch, 1998). This results in global hiring practices that favor Whiteness and nativism over teaching experience and local knowledge of educational and cultural values.

How can those involved in English language education challenge these systems and ideologies in a way that confronts their Capitalist histories and neoliberal realities in an effort to decolonize the field? We first need to look at the packaged promises of equality and advancement through English that are currently being sold through global and Westernized capitalism to educators and consumers all over the world. The field of TESOL, and in turn systems, policies, and practices of English language education, has continued to maintain the 
THE NEBRASKA EDUCATOR, VOLUME 6

"good-deeds" aspect of the job rather than "considering the way our field centers and values whiteness above all else, even to the point that we are willing to begrudgingly accept forms of discrimination" (Gerald, 2020, p. 47) through language learning materials, teacher-hiring practices, and gatekeepers of published knowledge. Utilitarian discourses and resulting neoliberal practices to English language education must be recognized for what they are and evaluated as to who they truly benefit.

Becoming (and staying) critically aware of our own teaching and research practices through reflection and critical scholarship offer educators and researchers strategies to help decolonize the field. ELT educators need to do the work of educating themselves on racial identity, race and language scholarship, and interdisciplinary literature so that they're better equipped to both understand the need for change and work towards meaningful action to challenge and bring about those changes in the field of English language education (Kramsch, 2019; Kubota, 2019). In order to de-center Whiteness and redistribute active voices and power in the field, journals and conferences need to include more non-White and non-native Englishspeakers. These individuals should also hold prominent seats on their respective boards and commissions and their voices, opinions, and experiences prioritized. Additionally, organizations such as TESOL and educational institutions need to be committed to moving forward at the faster pace of those seeking meaningful change instead of merely keeping the slow (and often immobile) pace of those most resistant to it. Merely, forming diversity committees and writing mission statements only serve to shield any discomfort that would come from challenging and actually changing the status quo.

ELT program curricula should focus on frameworks such as Critical Race Theory (CRT) in order to challenge the "good-deeds" approach and encourage critical reflection of the 


\section{THE NEBRASKA EDUCATOR, VOLUME 6}

Whiteness pervasive within the field (Macedo, 2019; Gerald, 2020). Practices of anti-racism such as prioritizing the agency of subjugated and minoritized people, making a commitment to uncover and promote their positioning, and validating worldviews and traditions of knowledge that challenge Euro-centric thinking can be effective in challenging the Westernized and colonial exclusion of knowledge. Scholars of both racial majority and minority groups should be committed to recognizing and challenging the entrenched status quo of racial and gender-based hierarchies and discourses in academia. It is only then that we can begin to untangle and unwind the epistemological, institutional, and individual racism that guides and informs so much of our work and practice. The field of TESOL and the entities under its umbrella cannot

Western capitalistic values that have given shape to contemporary neoliberal ideologies have, for too long now, greatly influenced the field of TESOL as a whole, essentially working to continue the cycle of injustice and inequality despite intentions to the contrary. Without more deliberate and critical analysis on how these discourse and ideological systems have shaped and continue to inform the field as we know it, it will be impossible for the field to truly serve in the equitable and just capacities in which it strives to place itself. The Black Lives Matter civil rights protests of 2020 are currently forcing many institutions operating within a Utilitarian discourse system to reckon with the colonized, racist, and neoliberal systems from which they grew. They have reminded us, once again, that these issues of inequality are layered under the repeated callouses of history, and we won't be able to dismantle current problems and move forward without a hard look at where we came from and how we got here. The "natural truths" about hard work and English language learning for upward mobility need to be recognized for the mythical and marketed neoliberal selling points that they truly are. As English language education and the field of TESOL itself has both benefited from and helped to perpetuate this 


\section{THE NEBRASKA EDUCATOR, VOLUME 6}

ideological marketing on a massive global scale, it is going to take quite a bit of active disruption to push the field and our practice forward into a place that truly can benefit and serve all equally. 
THE NEBRASKA EDUCATOR, VOLUME 6

\section{References}

Agar, M. (1996). Language shock: Understanding the culture of conversation.

Bonvillain, N. (2020). Language and institutional encounters. In Language, culture, and communication: The meaning of messages. Lanham, MD: Rowman \& Littlefield. pp. $354-388$

Gee, J. P. (2002). Millennials and Bobos, Blue's Clues and Sesame Street: A story for our times. Adolescents and literacies in a digital world, 51-67.

Gerald, J. (2020). Worth the risk: Towards decentering Whiteness in English language teaching. BC TEAL, 5(1). https://ojso.library.ubc.ca/index.php/BCTJ/article/view/345

Klees, S. J. (2020). Beyond neoliberalism: Reflections on capitalism and education. Policy Futures in Education, 18(1), 9-29.

Kramsch, C. (1998). "Language and culture.” Oxford University Press

Kramsch, C. (2019). Between globalization and decolonization. Decolonizing foreign language education: The misteaching of English and other imperial languages, 50-73.

Kubota, R. (2019). Confronting epistemological racism, decolonizing scholarly knowledge: Race and gender in applied linguistics. Applied Linguistics, amz033. https://doi.org/10.1093/applin/amz033

Litzenberg, J. (2020). "If I don't do it, somebody else will”: Covert neoliberal policy discourses in the decision-making processes of an intensive English program. TESOL Quarterly, n/a(n/a). https://doi.org/10.1002/tesq.563

Macedo, D. (2019). Rupturing the yoke of colonialism in foreign language education. Decolonizing Foreign Language Education. The misteaching of English and other imperial languages, 1-49. 


\section{THE NEBRASKA EDUCATOR, VOLUME 6}

Pennycook, A. (2007). The myth of English as an international language. Disinventing and reconstituting languages, 62, 90-115.

Scollon, R., Scollon, S. W., \& Jones, R. H. (2011). Intercultural communication: A discourse approach. John Wiley \& Sons. 